\title{
The climate of the Altiplano: observed current conditions and mechanisms of past changes
}

\author{
René Garreaud $^{\mathrm{a}}$, Mathias Vuille ${ }^{\mathrm{b}}$, Amy C. Clement ${ }^{\mathrm{c}, *}$ \\ a Departamento de Geofisica, Universidad de Chile, Santiago, Chile \\ b Climate System Research Center, Department of Geosciences, University of Massachusetts, Amherst, MA, USA \\ c Rosenstiel School of Marine and Atmospheric Science, University of Miami, 4600 Rickenbacker Causeway, Miami, FL, USA
}

Accepted 17 January 2003

\begin{abstract}
The large-scale controls on the climate of the South American Altiplano are investigated using local observations, reanalysis data and general circulation model experiments. The objective is to gain understanding of causes of climate variability and climate change by relating mechanisms that operate on timescales ranging from the intraseasonal to the glacial-interglacial. Our results suggest that, on all timescales, the climatic conditions on the Altiplano are closely related to the upper-air circulation, with an easterly zonal flow aloft favoring wet conditions and westerly flow causing dry conditions. Different factors influence the upper-air circulation on the different timescales. Intraseasonal variability is a reflection of the position and intensity of the Bolivian High, which is modulated by Rossby waves emanating from the midlatitude South Pacific. The annual cycle of dry winter and wet summer conditions is caused by the seasonal expansion of the equatorial easterlies in the upper troposphere, rather than direct insolation forcing over the Altiplano or moisture changes in the source area. Interannual variability is primarily related to changes in the mean zonal flow over the Altiplano, reflecting changes in meridional baroclinicity between tropical and subtropical latitudes, which in turn is a response to sea-surface temperature changes in the tropical Pacific. Orbitally forced changes in the land-sea contrast drive continental-scale circulation changes, which significantly alter the zonal flow over the Altiplano. On glacial-interglacial timescales, the contrast in heating between northern and southern hemispheres during the glacial leads to upper-air easterly anomalies throughout the tropics. On modern timescales the marked submonthly, seasonal and interannual changes of moisture over the Altiplano cannot be accounted for by moisture changes in the humid tropical lowlands. However, the model experiments suggest that cooler conditions during a glacial reduce moisture availability from the tropical lowlands, which counteracts the effect of the upper-level circulation, resulting in little overall change in precipitation. This observational and modeling analysis provides a physical framework for relating the mechanisms of both internal and forced climate change on the Altiplano on a wide range of timescales.
\end{abstract}

(C) 2003 Elsevier Science B.V. All rights reserved.

Keywords: Altiplano; modern climate; rainfall variability; past changes

* Corresponding author. E-mail address: aclement@rsmas.miami.edu (A.C. Clement).

0031-0182/03/\$ - see front matter (C) 2003 Elsevier Science B.V. All rights reserved.

doi:10.1016/S0031-0182(03)00269-4 


\section{Introduction}

The Andes cordillera, running continuously from north of the equator to the southern tip of South America, represents a formidable obstacle to the tropospheric circulation and acts as a climatic barrier between the sharply contrasting conditions over the continental lowlands to the east and the Pacific rim to the west. Along its central portion $\left(15^{\circ}-22^{\circ} \mathrm{S}\right)$, the widening of the Andes produces distinctive meteorological conditions that we refer to as the climate of the Altiplano. Interest in the climate of the Altiplano has grown in recent decades because its variability has a strong impact on the availability of water resources over this semi-arid region and the adjacent lowlands, and because of its links with continental-scale (and presumably hemispheric-scale) atmospheric circulation (e.g. Zhou and Lau, 1998; Lenters and Cook, 1999). Furthermore, as described elsewhere in this volume, paleoclimatic records indicate that environmental conditions in the central Andes have changed significantly in the past.

Here we investigate the mechanisms of climate variability and climate change of the Altiplano. In the first part of this paper, the current mean features, regular cycles and synoptic-to-interannual variability of the atmospheric circulation and precipitation over the Altiplano are described using local observations, gridded atmospheric reanalysis (Kalnay et al., 1996), and satellite-based cold cloud measurements (a rainfall proxy in the tropics), typically available for the last 20 years. The convective nature of the rainfall over the Altiplano and its controlling factors are discussed in Section 2, and in Section 3 we address the circulation patterns that give rise to rainfall and moisture variability on different timescales in modern climate. In the second part of the paper, we extend our understanding of the controls on the regional climate, especially in Altiplano rainfall, to the past. An atmospheric general circulation model (GCM) is used to investigate the response to known climatic forcings over the late Quaternary. Applying what is learned from the study of the modern climate in the first part of the paper, we focus on the large-scale changes in tropical climate that can lead to altered climatic conditions on the Altiplano. Conclusions are presented in Section 5.

\section{Current rainfall regime}

Rainfall over the Altiplano is largely produced by deep, moist convection which is the vigorous ascent of buoyant air from near-surface levels to the base of the tropopause $(\sim 15 \mathrm{~km})$ within fairly narrow regions (cumulonimbus cells; e.g. Houze, 1997). Such overturning of the atmosphere tends to neutralize the vertical distribution of air density when this distribution is disrupted, for instance, by the daytime surface heating over tropical landmasses. But even in the presence of a destabilization mechanism, two other ingredients are required to trigger deep convection: (1) a dynamical forcing to lift near-surface air parcels to their level of free convection and (2) sufficient water vapor near the surface so the convection becomes moist. If the atmospheric boundary layer $(\mathrm{ABL})$ is very moist and unstable almost any mechanical uplift could trigger deep convection, while if the ABL is very dry, moist convection will not be triggered regardless of potential instability of the atmosphere and the dynamical forcing.

The network of local observations from the central Andes is sparse, and our understanding of the details of the atmospheric phenomena is still somewhat limited. Nevertheless, some consistent patterns emerge from the available data and regional-scale numerical simulations. Throughout the year, midday solar radiation reaching the surface of the Altiplano ranges from 600 to $1100 \mathrm{~W}$ $\mathrm{m}^{-2}$ (e.g. Aceituno, 1998; Hardy et al., 1998), sufficient to destabilize the local tropospheric column (Rao and Erdogan, 1989; Garreaud, 1999). On the other hand, the complex topography of the region provides dynamical forcing at both local and regional scales most of the time. Altiplano rainfall is, however, largely restricted to the austral summer season (November to March, Figs. 1 and $2 b$ ), especially on the western side of the Altiplano, and is inherently episodic. On the interannual timescale the Altiplano also experiences 

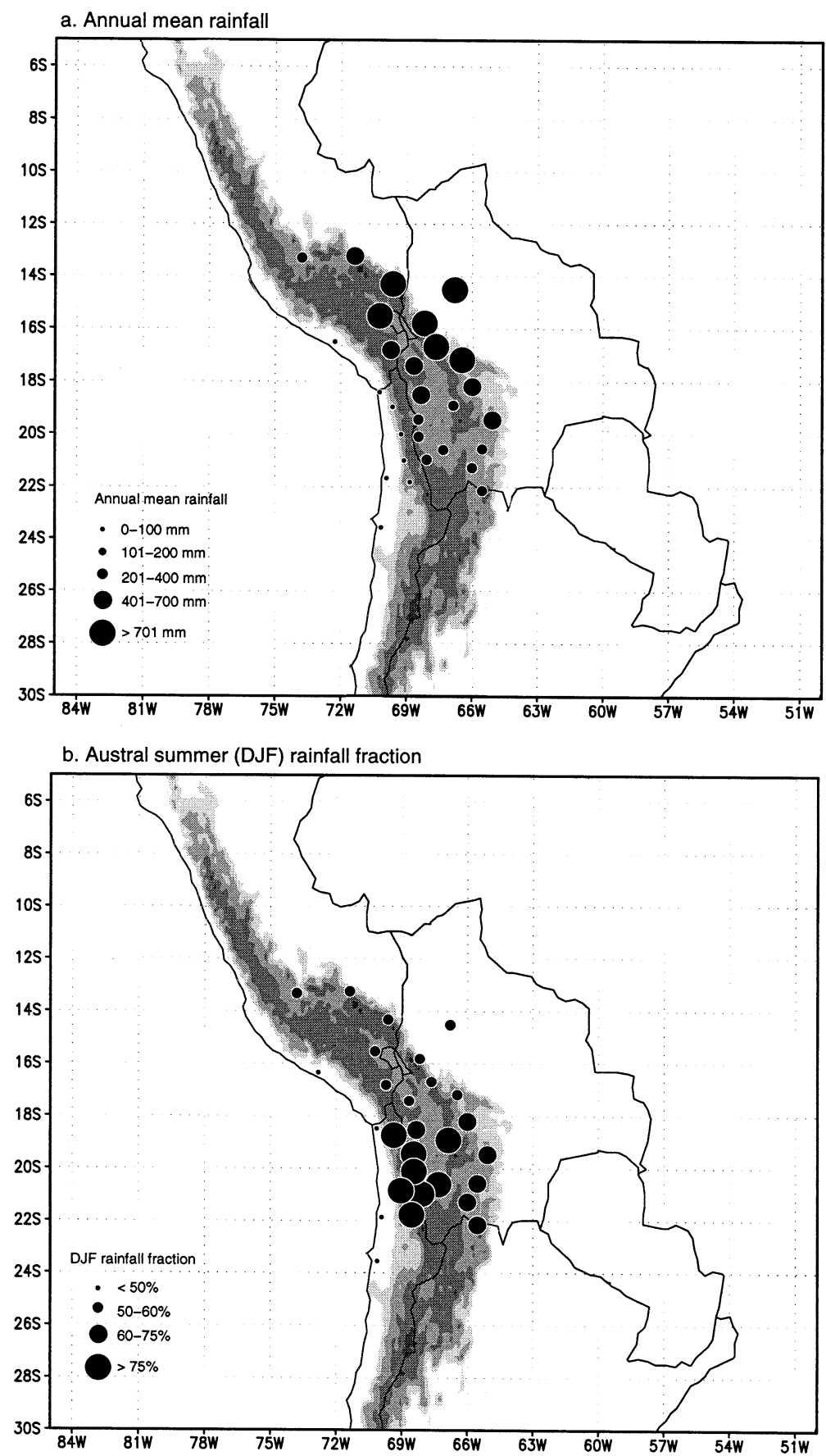

Fig. 1. (a) Terrain elevation (shaded) and rain-gauged annual mean rainfall over the central Andes and adjacent lowlands. Shading begins at $2000 \mathrm{~m}$ and gets darker every $1000 \mathrm{~m}$. Size of the symbol indicates the amount of rainfall. (b) As panel a, but the size of the symbol indicates the fraction of annual mean rainfall concentrated in the austral summer months (December, January and February). Adapted from Aceituno (1988). 
strong rainfall fluctuations. Such seasonal, intraseasonal (episodic) and interannual variability in convective rainfall observed in modern climate is thought to be locally controlled by the amount of near-surface water vapor $\left(q_{\mathrm{ns}}\right)$. As we will show in Section 3, this hypothesis is supported by local observations, which reveal that deep convection occurs almost exclusively when $q_{\mathrm{ns}}$ exceeds a threshold (typically $\sim 5 \mathrm{~g} / \mathrm{kg}$ ), and excedence of this threshold is usually accompanied by deep convection.

The moisture threshold for deep convection is substantially higher than the moisture values in the free tropospheric air at the level of the Altiplano $(\sim 600 \mathrm{hPa})$, indicating that moisture is transported from lower levels. The continental origin of the water vapor that feeds the convection over the Altiplano was suggested on the basis of an analysis of the atmospheric circulation (Fuenzalida and Rutllant, 1987), and subsequently confirmed by more sophisticated trajectory analyses (Vuille et al., 1998) and isotopic analysis of rainfall (e.g. Chaffaut et al., 1998). The deep mixed layer and the prevailing unstable conditions over the continental lowlands to the east of the central Andes makes the moist air over this region readily available for transport to upper levels. The pronounced west-to-east gradient in rainfall (Fig. 1) and humidity within the Altiplano is consistent with the eastern, continental source of moisture. The moist, cool air over the Pacific ocean immediately to the west of the central Andes is limited laterally by the coastal topography, and vertically by a strong, persistent temperature inversion at about $800 \mathrm{~m}$ above sea level (e.g. Rutllant and Ulriksen, 1979). The inversion is maintained by the large-scale subsidence over the subtropical SE Pacific, which also leads to the hyper-arid conditions over the Atacama desert and the western slope of the central Andes. Thus, the moist air over the subtropical SE Pacific does not contribute to the Altiplano water budget in modern climate.

\section{Moisture and rainfall variability}

In this section we describe the patterns of at- mospheric circulation that give rise to moisture and rainfall variability over the Altiplano on different timescales. The most obvious fluctuations in Altiplano rainfall are those associated with the diurnal and annual cycles. The maximum frequency and intensity of the rainfall occurs between afternoon and early night (Garreaud and Wallace, 1997; Aceituno, 1998) and is produced by the insolation-driven surface heating and the consequent destabilization of the local lower troposphere. The rainfall over the Altiplano is largely concentrated in the austral summer months, especially along its southwestern part, where more than $70 \%$ of the precipitation occurs from December to February (Figs. 1 and 2b). Superimposed on these regular cycles, rainfall over the Altiplano exhibits significant fluctuations on the intraseasonal and interannual timescales. We begin by describing the most rapid fluctuations (beyond the diurnal cycle), since these will serve as a foundation for understanding variability on seasonal, interannual and longer timescales.

\subsection{Intraseasonal variability}

Inspection of station data over the Altiplano reveals that within the summer season, rainy days tend to cluster in sequences of about a week in duration (rainy episodes), which are separated by dry episodes of similar length (e.g. Aceituno and Montecinos, 1993; Lenters and Cook, 1999). Note that the typical duration of these rainfall fluctuations ( $T \sim 15$ days) is twice as long as the synoptic periods that characterize midlatitude weather, but less than half of the period of the most prominent intraseasonal variability in the tropics $(T \sim 30-60$ days $)$. Convective storms often organize in mesoscale bands encompassing much of the central Andes (Garreaud, 2000), leading to a spatially coherent pattern of intraseasonal rainfall variability. Similarly, time series of near-surface mixing ratio $q_{\mathrm{ns}}$ from stations within the Altiplano exhibit alternations of welldefined episodes of moist $\left(q_{\mathrm{ns}} \geq 5 \mathrm{~g} / \mathrm{kg}\right)$ and dry $\left(q_{\mathrm{ns}}<3 \mathrm{~g} / \mathrm{kg}\right)$ conditions. Significant simultaneous correlation among moist and dry episodes at different sites is indicative of a basin-wide mode of moisture variability during the summer season 
which is superimposed on the mean west-to-east moisture gradient (Garreaud, 2000).

Given the spatially coherent patterns of convective and moisture variability, we can use areaaveraged quantities to study their relationship. Fig. 2d shows, for the austral summer 1993/94, daily mean values of the $600 \mathrm{hPa}$ mixing ratio from the NCEP-NCAR reanalysis and satellite measurements of outgoing longwave radiation (OLR) averaged over the Altiplano. In the tropics, values of OLR $<200 \mathrm{~W} \mathrm{~m}^{-2}$ are produced by cold, high clouds, and therefore used as a proxy of deep convection and convective rainfall (e.g. Meisner and Arkin, 1987). There is a clear correspondence between moist periods with active convection (presumably rainy episodes) and dry periods with suppressed convection. Vertical profiles of thermodynamic variables from a field campaign in the western side of the Altiplano (Aceituno and Montecinos, 1997b) shed light on the physical mechanism for such an association: the episodic increments of $q_{\mathrm{ns}}$ produce a net increase of the low-level potential energy available for moist convection (and hence rainfall), which is triggered by local updraft over this complex terrain (Garreaud, 1999).

Fig. 2c shows the reanalyzed daily mean zonal wind over the Altiplano, featuring a strong easterly-wet/westerly-dry relationship. The zonal flow anomalies over the central Andes have been associated with changes in the intensity and position of the Bolivian high, a prominent upper-level anticyclonic circulation with its center at roughly $15^{\circ} \mathrm{S}, 65^{\circ} \mathrm{W}$ during the austral summer (see Lenters and Cook, 1997, for a review). Stronger than average easterly winds aloft over the central Andes are associated with a reinforcement and southward displacement of the Bolivian high, while westerly anomalies are associated with a weakening of the Bolivian high (Aceituno and Montecinos, 1993; Vuille et al., 1998; Lenters and Cook, 1999; Garreaud, 1999). The fluctuations in the position and intensity of the Bolivian high are in turn associated with quasi-stationary Rossby waves emanating from the midlatitude South Pacific and amplifying over subtropical South America (Garreaud, 1999). It has been shown that changes in the large-scale circulation over the central part of the continent are also instrumental for the reoccurrence of a characteristic pattern in the intraseasonal summertime rainfall variability over subtropical South America (e.g. Nogues-Paegle and Mo, 1997). The Altiplano rainfall anomalies often coincide with anomalies of the same sign over southeast Bolivia and central Argentina, and tend to be out-of-phase with rainfall anomalies over the eastern side of the continent and the adjacent subtropical Atlantic (Aceituno and Montecinos, 1997a; NoguesPaegle and Mo, 1997; Garreaud, 1999).

What is the physical link between the upperlevel flow over the central Andes and moisture variability on the Altiplano? Mid- and upper-tropospheric transport alone cannot explain significant moisture changes, since the air is too dry at these levels. Mesoscale numerical simulations indicate that the moisture transport is actually produced by regional circulation over the eastern slope of the Andes that draws moist air from the ABL over the nearby continental lowlands (Garreaud, 1999). Upslope flows are also observed over the western side of the Andes, transporting dry air from the coastal desert into the Altiplano. These regional-scale circulation patterns are primarily forced by the heating of the sloping terrain (e.g. Whiteman, 1990), but the large-scale flow aloft can modulate their strength and duration through the downward mixing of momentum at the top of the ABL. Model results show that easterly flow in the upper troposphere (300-100 hPa) over the central Andes leads to stronger (weaker) than average upslope flow over the eastern (western) slope and easterly low-level winds within the Altiplano ABL, increasing the moisture transport from the continental lowlands that feeds the deep convection (Garreaud, 1999). This is shown schematically in Fig. 3. The opposite effect on the regional circulation is seen in cases of westerly flow aloft, hindering the moisture transport from the east and suppressing moist convection over the Altiplano. Thus, the link between the large-scale, upper-level flow anomalies over the central Andes and the local, near-surface moisture changes on the Altiplano occurs throughout the dynamical modulation of the regional slope circulation patterns. 
Moisture (and hence rainfall) variability over the Altiplano could also arise from local moisture and rainfall variability over the lowlands to the east of the Andes. However, low-level moisture fluctuations over this latter region have typical amplitudes of about half those on the Altiplano, and they occur on shorter timescales $(T \sim 2-5$ days) (Garreaud, 2000). Furthermore, low-level
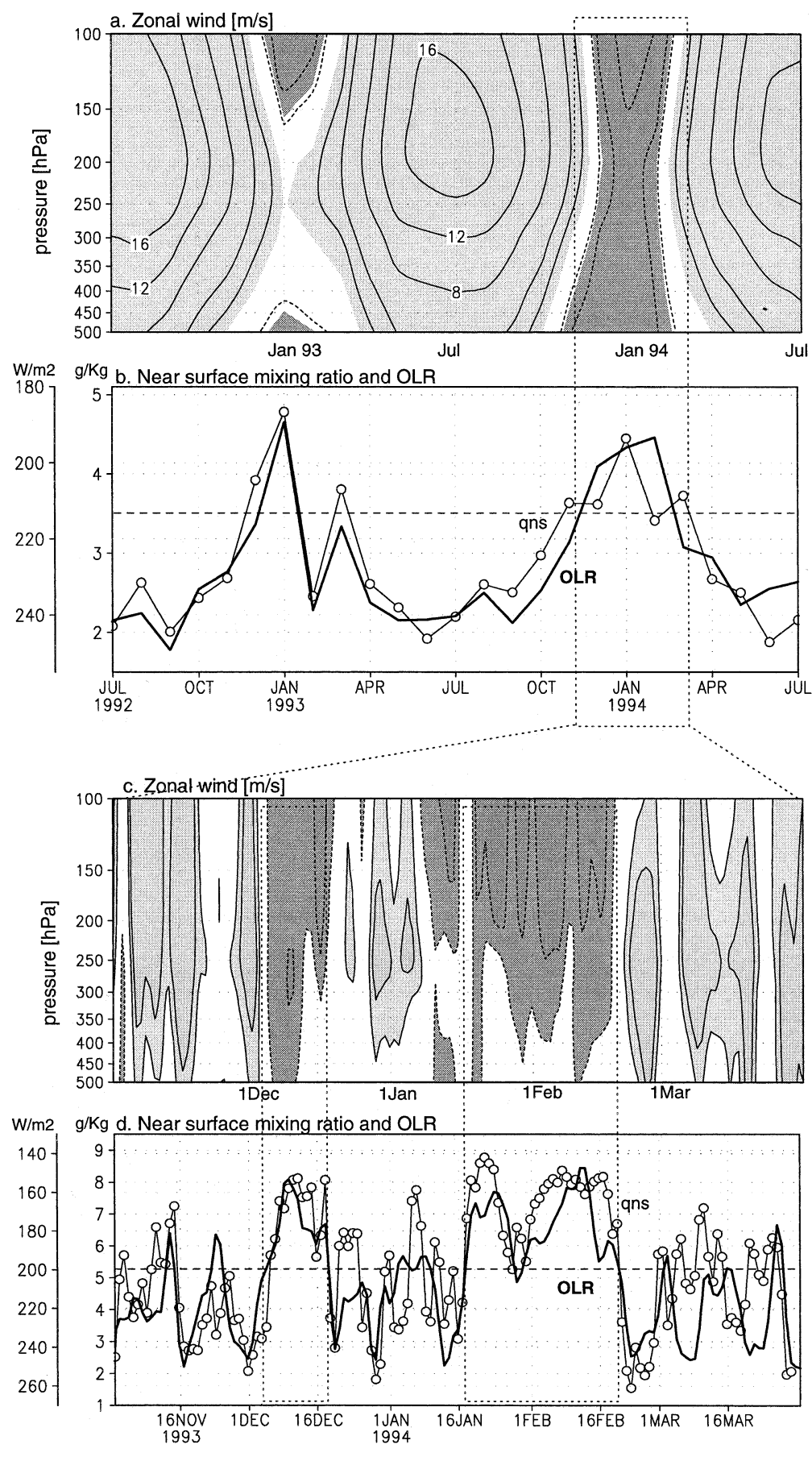
moisture content over the continental lowlands is always higher than about $12 \mathrm{~g} / \mathrm{kg}$, which suggests that moisture variability over the Altiplano is not directly controlled by moisture changes in its source region. Similarly, summertime rainfall on the nearby continental lowlands is distributed over a large number of rainy days, and a causal linkage between lowland and Altiplano convection has not yet been documented.

\subsection{The seasonal cycle}

Although the pronounced seasonal cycle that characterizes the Altiplano rainfall is ultimately driven by the solar cycle, it is not directly forced by insolation over the Altiplano. Solar radiation reaching the surface varies less than $30 \%$ from winter to summer and the maximum insolation occurs 1-2 months before the rainy season. The seasonal cycle in rainfall is instead related to changes in the zonal wind in the middle and upper troposphere over the central Andes (Fig. 2a,b).

Dynamically tied to the tropospheric-mean temperature contrast between the tropics and the midlatitudes, the subtropical westerly jet stream over western South America reaches its maximum intensity and northernmost position $\left(27^{\circ} \mathrm{S}\right)$ during winter and early spring. Consistently, mean westerly flow prevails in the middle and upper troposphere over the Altiplano from May to October and, despite synoptic and intraseasonal variability in the zonal flow, days with easterly winds aloft occur less than $5 \%$ of the time. The prevailing strong westerly flow aloft hinders the regional moisture transport over the eastern slope of the Andes, resulting in very low near-surface moisture content over the Altiplano $\left(q_{\mathrm{ns}}<2 \mathrm{~g} / \mathrm{kg}\right)$ that cannot support convective rainfall. Wintertime rainfall, if any, is associated with upper-level southern hemisphere $(\mathrm{SH})$ midlatitude disturbances tracking abnormally north of their mean path (Vuille and Ammann, 1997).

By late spring the weakening of the meridional temperature gradient leads to a weakening and southward displacement of the subtropical jet stream. At the same time, deep convection begins to develop over the central part of the continent (e.g. Horel et al., 1989), including the southern part of the Amazon basin. The wide area of continental convection is connected with the convergence zones over the tropical Atlantic and Pacific (the oceanic Intertropical Convergence Zones (ITCZs)), but it is not a mere shift of the ITCZ into subtropical latitudes. The changes in the subtropical jet stream in conjunction with the establishment of the Bolivian high (largely in response to the continental convection) result in a southward expansion of the equatorial belt of easterly winds, so that weak mean easterly flow prevails in the middle and upper troposphere over the Altiplano from December to March (Fig. 2a). At the height of the austral summer, the transition from easterly to westerly flow at $200 \mathrm{hPa}$ occurs at about $20^{\circ} \mathrm{S}$, the southern edge of the Altiplano. The superposition of transient fluctuations (caused by Rossby waves from midlatitudes) on the summertime background circulation leads to a larger number of days with easterly flow aloft over the central Andes. This results in an enhanced moisture transport into the Altiplano, and hence the development of the rainy season during the austral summer (Fig. 2a,b).

Admittedly, the moisture content in the ABL over the continental lowlands to the east of the Andes has a seasonal cycle similar in phase to that over the Altiplano. Even in winter, however, lowland ABL moisture is very high (over $12 \mathrm{~g} / \mathrm{kg}$ ), supporting the notion that the seasonal changes in

Fig. 2. (a) Monthly mean zonal wind over the Altiplano from July 1992 to July 1994 . Only shown are contours $-4,-2,+2,+4$, $+8,+12$ and $+16 \mathrm{~m} / \mathrm{s}$. Light (dark) shading indicates westerly (easterly) flow. (b) Monthly mean near-surface mixing ratio and OLR over the Altiplano for the same period as in panel a. (c) Daily mean zonal wind over the Altiplano from November 1, 1993, to March 31, 1994. Zonal wind is contoured every $2 \mathrm{~m} / \mathrm{s}$, negative values in dashed line, and the zero line is omitted. Light (dark) shading indicates westerly (easterly) flow. (d) Daily mean near-surface mixing ratio and OLR over the Altiplano for the same period as in panel a. Notice that in panels $b$ and d, OLR scale has been inverted so upper points indicate deep convection. In all cases, values over the Altiplano correspond to the area average $17.5^{\circ}-20^{\circ} \mathrm{S}, 67.5^{\circ}-70^{\circ} \mathrm{W}$. Wind and moisture data from NCEP-NCAR reanalysis. 

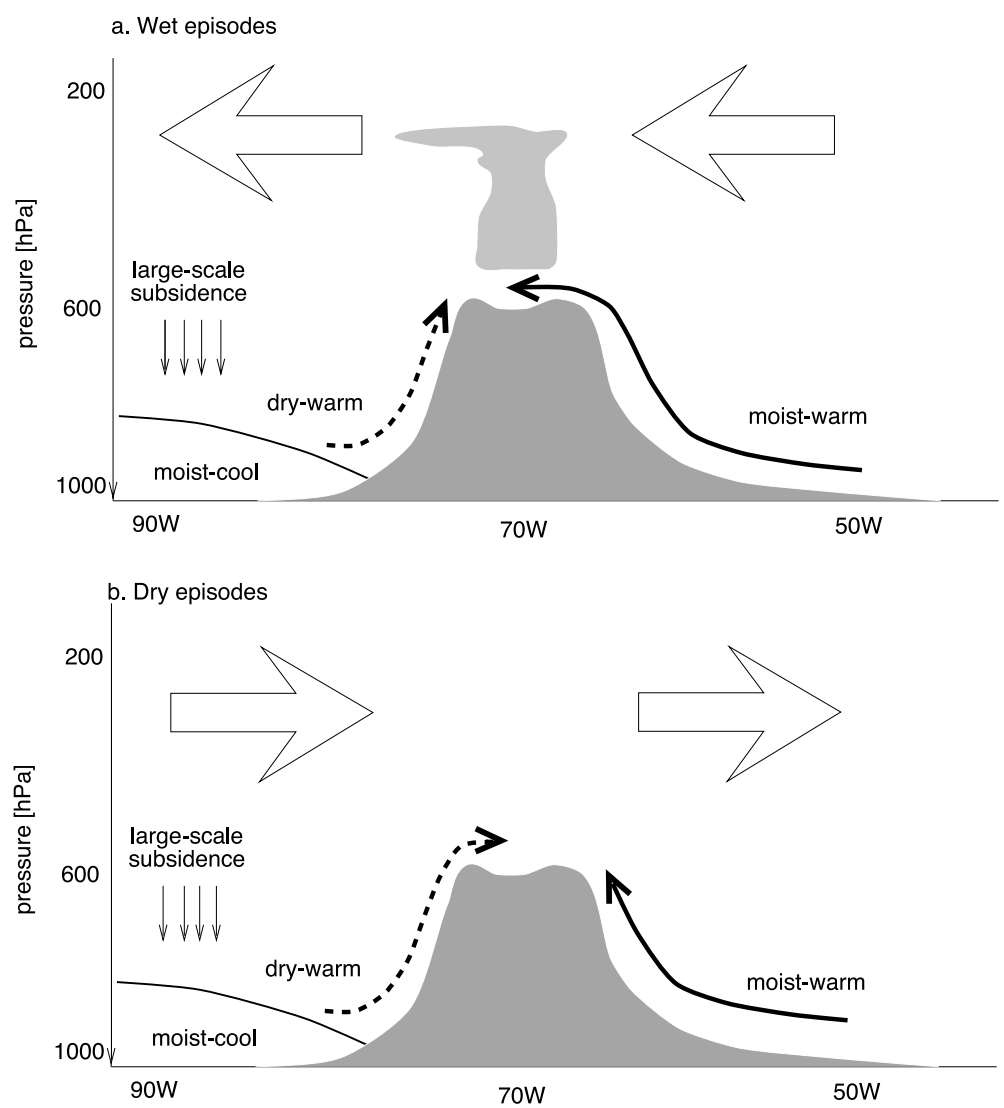

Fig. 3. Schematic representation of the circulation patterns and different air masses over and adjacent to the central Andes, in a vertical-longitude section at the latitudes of the Altiplano, for (a) rainy episodes and (b) dry episodes. Large, open arrows indicate the sense of the upper-level, large-scale flow. Solid (dashed) curves represent the transport of moist (dry) air by the regional circulation over the Andean slopes. Thin vertical arrows represent the large-scale subsidence over the subtropical SE Pacific that maintains the strong trade inversion (solid line).

Altiplano moisture are controlled by changes in the moisture transport, rather than by moisture changes in its source region.

\subsection{Interannual variability}

On the interannual timescale, the Altiplano experiences strong precipitation fluctuations, ranging from extremely dry to very wet austral summer conditions. Between 1957 and 1996, DJF precipitation recorded at Copacabana $\left(16.2^{\circ} \mathrm{S}, 69.1^{\circ} \mathrm{W} ; 3815 \mathrm{~m}\right)$, located on the shore of Lake Titicaca, for example, ranged from 203 $\mathrm{mm}$ in $1990 / 91$ to $850 \mathrm{~mm}$ in $1983 / 84$. In the more arid southwestern part of the Altiplano the fluctuations are even more impressive, as indicated by the station Coyacagua in northern Chile $\left(20^{\circ} \mathrm{S}\right.$, $68.8^{\circ} \mathrm{W} ; 3990 \mathrm{~m}$ ) where the minimum DJF precipitation sum recorded was $11 \mathrm{~mm}$ in 1982/83, while in the next rainy season, 1983/84, the maximum record was set with $277 \mathrm{~mm}$. This strong interannual variability of summer precipitation has been described in a number of studies and there is a general agreement that a significant fraction of this variability is related to the $\mathrm{El}$ Niño Southern Oscillation (ENSO) phenomenon (e.g. Thompson et al., 1984; Aceituno, 1988; Ronchail, 1995; Lenters and Cook, 1999; Vuille, 1999; Vuille et al., 2000a; Arnaud et al., 2001; Garreaud and Aceituno, 2001). All of these studies concluded that El Niño years (warm phase of ENSO) tend to be dry, while La Niña years 
(ENSO cold phase) are often associated with wet conditions on the Altiplano. However, dry La Niña years and wet El Niño years are not completely uncommon, which indicates that the relationship between sea-surface temperature anomalies (SSTA) in the tropical Pacific and precipitation anomalies in the central Andes is not simple.

Fig. 4 shows the time series of the first principal component of DJF precipitation on the Altiplano (PC1) between 1957 and 1996, which accounts for $49.8 \%$ of the total variance and represents the primary mode of summer precipitation variability. A more detailed description of the PC analysis can be found in Vuille et al. (2000a). Fig. 4 also includes the seasonal mean (DJF) values of the NINO-3.4 index (SSTA averaged over $5^{\circ} \mathrm{N}-5^{\circ} \mathrm{S}$, $120^{\circ}-170^{\circ} \mathrm{W}$ ) and the $200 \mathrm{hPa}$ zonal wind anomalies over the Altiplano (average of four $2.5^{\circ} \times 2.5^{\circ}$ latitude-longitude grid cells centered at $17.5^{\circ} \mathrm{S} /$ $20.0^{\circ} \mathrm{S}$ and $67.5^{\circ} \mathrm{W} / 70^{\circ} \mathrm{W}$ ).
The correlation of $\mathrm{PC} 1$ with the oceanic index reveals a significant dependence of austral summer precipitation on tropical Pacific SSTA $(r=-0.46)$. Increased precipitation on the Altiplano occurs during the cold phase of ENSO (La Niña), such as in $1970 / 71$ or $1973 / 74$, while the ENSO warm phase (El Niño) tends to suppress rainfall (i.e. in 1965/66, 1982/83 or 1991/92, see Fig. 4a). Also noteworthy is the considerable degree of persistence in the DJF precipitation signal, with anomalies of the same sign clustering in wet and dry phases such as the wet 1970s (nine out of 10 years with above-average precipitation) and the dry late 1980s and early 1990s (five consecutive drought years between 1988 and 1992). In the westernmost part of the Altiplano (not shown) this signal is even more pronounced, featuring a strong decadal-scale variability (Vuille et al., 2000a). Finally, Fig. 4a also reveals a few distinct years, where the ENSO-precipitation relationship fails. Wet El Niño years (most prominent in 1972/
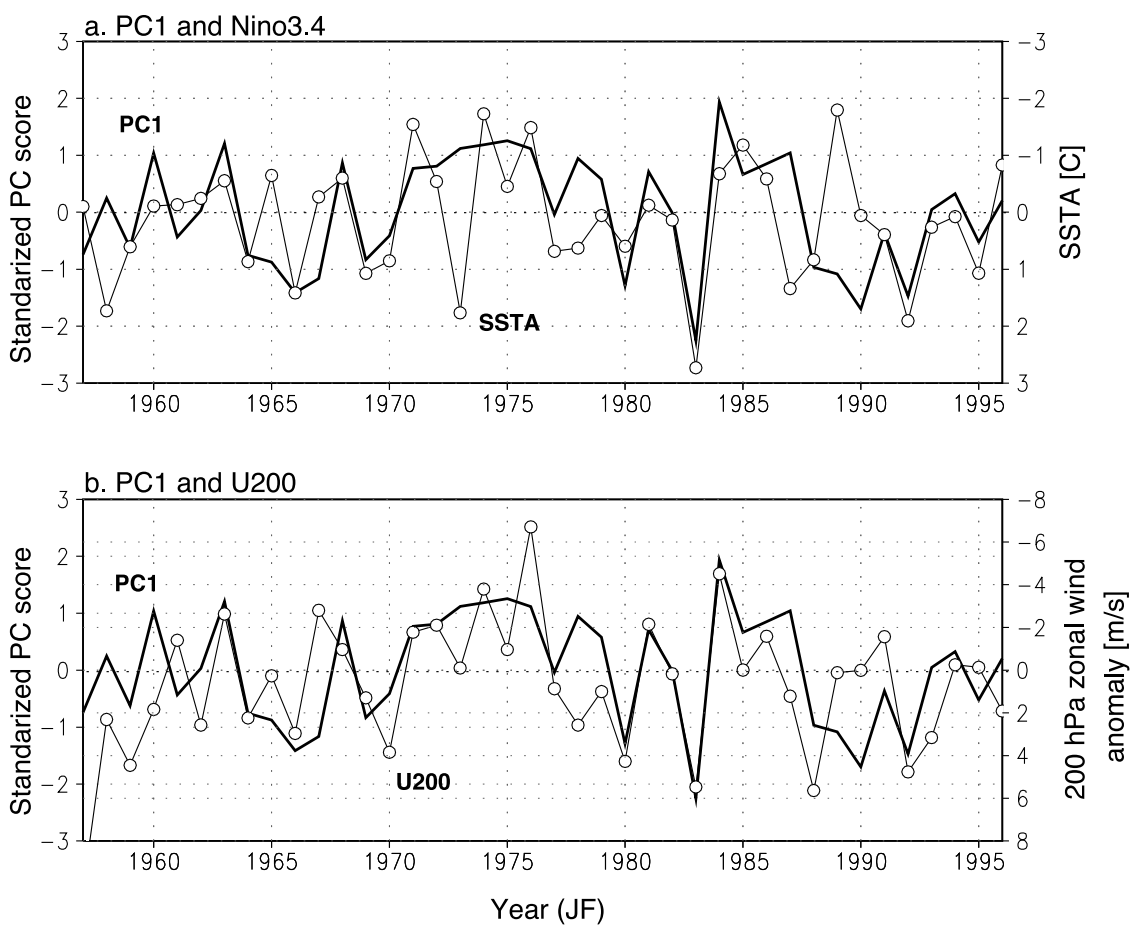

Fig. 4. Time series of unrotated principal component 1 of DJF precipitation in the Altiplano (PC1, thick line) and (a) NINO3.4 index, (b) $200 \mathrm{hPa}$ NCEP-NCAR zonal wind anomalies over grid boxes $17.5^{\circ}-20^{\circ} \mathrm{S}, 67.5^{\circ}-70^{\circ} \mathrm{W}$, between 1957 and 1996 . Reference period for the anomalies is 1961-1990. Years are indicated for the JF part of the respective season, i.e. 1957 represents DJF 1956/57. Please note that the scale is reversed for both (a) DJF-NINO3.4 and (b) DJF U200. 
73) or dry La Niña years (i.e. in 1988/89) are possible. We will review the reasons for these anomalies later on in this section.

Central Andean precipitation shows a strong linear relationship with the $200 \mathrm{hPa}$ zonal winds above the Altiplano $(r=-0.59)$, that is, wet (dry) summers are related to mean easterly (westerly) flow in the upper troposphere (Fig. 4b). This suggests that the mechanisms responsible for wet episodes on the intraseasonal timescale as presented in the previous section are also at play on interannual timescales. Summers with mean easterly flow feature a higher fraction of days with easterly winds (Garreaud and Aceituno, 2001). Interannual precipitation variability is, therefore, to first order a reflection of an increase in the number of wet (dry) episodes within a rainy season rather than higher (lower) rainfall intensity.

Of course $200 \mathrm{hPa}$ zonal wind anomalies and tropical Pacific SSTA are not independent. The upper-level winds are part of the atmospheric response to the amplitude and spatial pattern of the SSTA in the tropical Pacific and thus provide the physical link between an oceanic forcing and climate in the central Andes (e.g. Garreaud and Aceituno, 2001). To illustrate this conceptual physical framework we have correlated the Altiplano precipitation time series $\mathrm{PC} 1$ with contemporaneous tropical Pacific SSTA, $200 \mathrm{hPa}$ geopotential height and wind. The SSTA correlation field (Fig. 5a) reveals significant negative correlations over almost the entire tropical Pacific and features the typical ENSO-tongue centered on the equator and extending westward beyond the dateline. At the same time, positive correlations extend from west of $160^{\circ} \mathrm{E}$ at the equator in a $\mathrm{V}$-shape fashion to $30^{\circ} \mathrm{N}$ and $30^{\circ} \mathrm{S}$ in the southwestern and northwestern part of the tropical $\mathrm{Pa}$ cific basin. The SSTA correlation field thus features all the characteristics of the canonical ENSO mode (e.g. Garreaud and Battisti, 1999) and, although local correlations do not surpass -0.56 , yields strong evidence for a significant ENSO influence on DJF Altiplano precipitation.

The regression map in Fig. 5c indicates the strength (in $\mathrm{m} \mathrm{s}^{-1}$ ), sign and significance of local anomalies at each grid cell associated with a unit anomaly of the reference PC1 time series (e.g.
Garreaud and Aceituno, 2001). There is a significant relationship between Altiplano precipitation and zonal wind anomalies upstream and downstream of the Altiplano, which in turn are the result of a steep meridional pressure gradient between tropical and subtropical latitudes. This is consistent with the easterly/wet-westerly/dry relationship derived on the synoptic timescale (see Section 3.1) and confirms the results from earlier studies (Aceituno and Montecinos, 1993; Vuille et al., 1998; Vuille, 1999; Vuille et al., 2000a,b; Garreaud and Aceituno, 2001). The pattern is largely of a tropical nature, with winds responding to the changes in meridional baroclinicity (temperature gradient). Over the rest of the tropics both geopotential height and wind anomalies bear strong resemblance to ENSO-related circulation anomalies (Garreaud and Aceituno, 2001). Accordingly, the pattern in Fig. 5 suggests that wet summers on the Altiplano are associated with an ENSO-related cooling of the tropical Pacific (Fig. 5a), a shrinking of the tropical troposphere (Fig. 5b) and thus enhanced easterly flow over the Altiplano (Fig. 5c) as a response to the changes in meridional baroclinicity between tropical and subtropical latitudes. During dry summers the pattern is reversed.

Given this causal mechanism, the question remains why some El Niño (La Niña) years fail to produce dry (wet) conditions on the Altiplano. The most prominent mismatches that stand out in Fig. 4a are 1972/73 (wet El Niño year) and 1988/89 (dry La Niña year). As shown, rainfall anomalies on the Altiplano are highly sensitive to the location and intensity of the zonal wind anomalies, which in turn are a result of the tropical warming (cooling) during El Niño (La Niña) periods. In both 1972/73 and 1988/89, however, the spatial pattern of the tropical warming (cooling in 1988/89) was anomalous, which in turn resulted in an anomalous location of the zonal wind anomalies (Garreaud and Aceituno, 2001). Another reason for the rather weak relationship is the short time window of the Altiplano rainy season (DJF) and the timing of the ENSO-peak phase. Although ENSO is to some degree phaselocked to the annual cycle, and its mature phase tends to coincide with the Altiplano rainy season, 

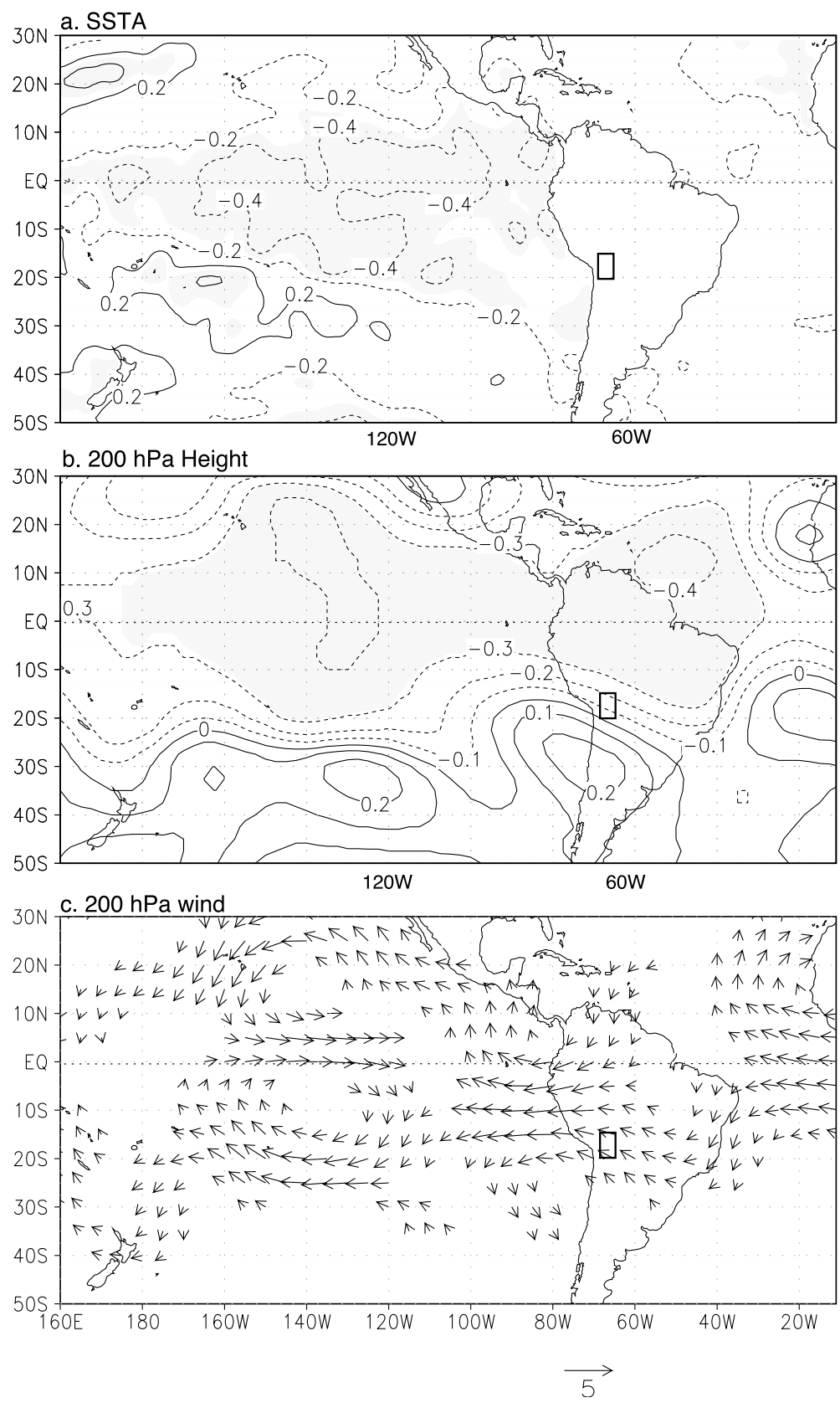

Fig. 5. (a) Correlation field of PC1 with DJF SSTA (GISST 2.3a). Contour interval is 0.2 , negative contours are dashed and the zero line is omitted. (b) As in panel a, but for DJF $200 \mathrm{hPa}$ geopotential height anomalies. Contour interval is 0.1 , negative contours are dashed. (c) Regression field of PC1 with DJF $200 \mathrm{hPa}$ wind anomalies between 1957 and 1996. Values significant at the $95 \%$ confidence level based on two-tailed Student's $t$-test are shaded in gray in panels a and $\mathrm{b}$. Wind vectors in panel c are shown only if either zonal or meridional component is significant at $95 \%$-confidence level. Scale for wind vectors in panel c is given below. Reference period for the anomaly fields is 1961-1990. Wind and geopotential height fields from NCEP-NCAR reanalysis. 
this is not always the case. In addition, the apparent change in the ENSO behavior after 1976 (e.g. Trenberth and Stepaniak, 2001) may also have modified the ENSO-Altiplano rainfall relationship. Finally, because of the spatial variability of precipitation over the larger Altiplano region, the choice of the precipitation index used can influence the statistical significance of its correlation with ENSO. Because the moisture source for Altiplano precipitation lies to the east of the Andes, the western part of the Altiplano, being further away from this source, is more sensitive to ENSO-induced zonal winds aloft. While the eastern cordillera may still receive some precipitation during a phase of El Niño-induced westerly wind anomalies, this is hardly the case for the more remote western part of the Altiplano. Therefore the western Altiplano regions tend to show a stronger ENSO signal than the eastern parts (Vuille et al., 2000a), an issue that should be considered when interpreting paleo-ENSO records.

There is currently no evidence for a significant influence of tropical Atlantic SSTA on Altiplano precipitation variability (Vuille et al., 2000a). A number of studies have highlighted such an influence over the tropical lowlands of South America (Enfield, 1996; Nobre and Shukla, 1996), especially in NE Brazil (e.g. Mechoso et al., 1990), the Amazon basin (e.g. Marengo and Hastenrath, 1993), and even along the eastern slopes of the northern tropical Andes (Vuille et al., 2000b). In all those regions the Atlantic influence is associated with a change in the strength and intensity of the trade winds and thus with the moisture influx into the tropical continent. The mixing ratio of the Altiplano near-surface layer, however, is largely decoupled from the mixing ratio of the tropical lowlands to the east (Garreaud, 2000). The moisture availability in the tropical lowlands is thus not a dominant regulating factor for Altiplano precipitation.

The significant ENSO-related cooling or warming of the tropical troposphere also leads to a direct relationship between ENSO phases and near-surface temperature fluctuations over the Altiplano (Vuille et al., 2000a; Vuille and Bradley, 2000). The spatial pattern of temperature anoma- lies over the Altiplano is quite homogeneous and responds to Pacific SSTA in the central equatorial Pacific with a lag of approximately 1-2 months. On average, the temperature difference between the ENSO warm (El Niño) and cold phase (La Niña) ranges between 0.7 and $1.3^{\circ} \mathrm{C}$ (Vuille et al., 2000a). Above-normal tropical Pacific SSTs during El Niño phases cause increased evaporation and precipitation over the central equatorial Pacific, thereby heating the atmosphere through the release of latent heat. The tropospheric warming extends beyond the central equatorial Pacific, affecting neighboring regions such as the central Andes. In addition, decreased cloudiness (and hence, increased insolation) and increased subsidence over the central Andes can also contribute to the observed temperature increase during $\mathrm{El}$ Niño.

\section{Mechanisms of past changes}

\subsection{Model description and experimental design}

Having gained some understanding of the modern, large-scale controls on precipitation over the Altiplano on various timescales, we now investigate how these factors are influenced by known external climate forcings of the past. For this we use a climate model that consists of three components: (1) the Geophysical Fluid Dynamics Laboratory atmospheric GCM, (2) a heat and water balance model over the continents, and (3) a simple mixed-layer ocean model. The atmosphere is run at R30 resolution, which corresponds to a grid spacing of approximately $2.25^{\circ}$ latitude $\times 3.75^{\circ}$ longitude, and there are 20 vertical levels. The ocean mixed layer is treated as a static, isothermal layer of $50 \mathrm{~m}$ depth. An additional heat flux term is applied in the ocean that varies geographically and seasonally in order to represent the horizontal heat transport by ocean currents. See Broccoli (2000) for additional model details.

Experiments were performed in order to investigate the atmosphere-mixed layer response to changes in the Earth's orbital parameters and to glacial boundary conditions separately. While 
global ice volume and its associated changes in land surface, atmospheric composition and ocean circulation are thought to be linked to the orbital forcing (Broecker, 1995), the direct orbital forcing in the tropics is large and likely to have a very different climatic signature than the glacial forcing. In this paper, we will focus on the effect of precession of the equinoxes, which varies on an approximately $20 \mathrm{kyr}$ timescale, and is modulated by longer-term (100 and $400 \mathrm{kyr}$ ) changes in the eccentricity of the Earth's orbit. The response to changes in the tilt of the Earth's orbit will be examined elsewhere. The following set of experiments was performed: (1) A control run with modern boundary conditions; (2) a Last Glacial Maximum simulation with altered sea level, landsea distribution, continental ice, surface elevation, atmospheric $\mathrm{CO}_{2}$ and orbital parameters at $21 \mathrm{kyr}$ (see Broccoli, 2000); (3) a run in which the phase of the precessional cycle is set to be $180^{\circ}$ out of phase with the modern, the eccentricity, axial tilt and all other boundary conditions are set to their modern values; (4) same as (3) but with the phase of the precessional cycle at $90^{\circ}$ out of phase with the modern. The difference between experiments
(1) and (2) gives an estimate of the effect of the glacial forcing on the atmosphere-mixed layer ocean system. The reader is referred to Broccoli (2000) for an analysis of the model sensitivity to glacial conditions. The set of experiments (1), (3) and (4) can be used to calculate the linear response of the system over a full precessional cycle. That is, we assume that a given climate variable can be written as: $x=[x]+\operatorname{Aesin}(\lambda+\varphi)$. Analyses of existing runs with the GFDL model indicate that this assumption is correct for most variables (A.J. Broccoli, C. Jackson, personal communication). From experiments (1), (3) and (4), we can determine the parameters of the fit to this general form of the sine function, $[x], A$ and $\varphi$. Then for a given value of $e$, the eccentricity, and $\lambda$, the longitude of perihelion, we can calculate the linear response to the full precessional forcing for a given variable. We develop time series for the glacial response by scaling the glacial-modern difference by the SPECMAP oxygen isotope anomaly over the last 150 kyr (Imbrie et al., 1982). While we do not claim that the response to glacial forcing is truly this linear, the time series allows a qualitative evaluation of the relative impacts of preces-

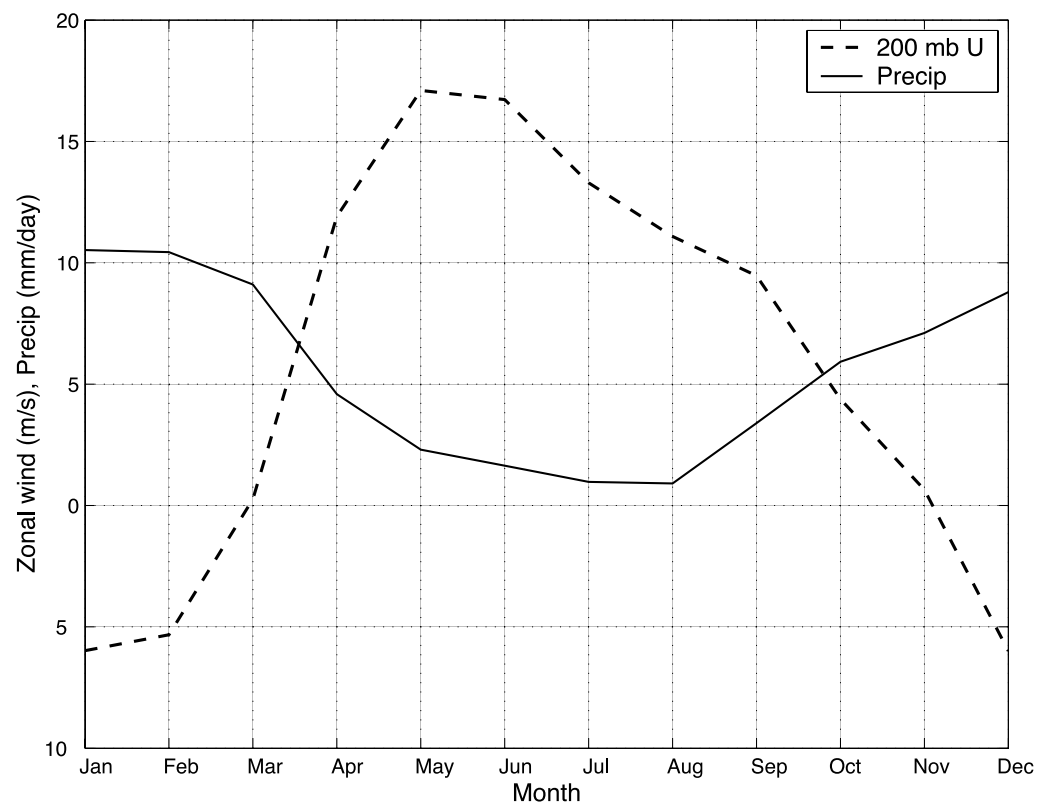

Fig. 6. The seasonal cycle (for modern boundary conditions) in the GFDL model of precipitation (solid, $\mathrm{mm} / \mathrm{day}$ ) and zonal wind at $200 \mathrm{hPa}$ (dashed, $\mathrm{m} / \mathrm{s})$ over the central Altiplano $\left(60^{\circ}-78^{\circ} \mathrm{W}\right.$ and $\left.20^{\circ}-10^{\circ} \mathrm{S}\right)$. 
sional forcing and glacial forcing. A similar methodology was applied by Prell and Kutzbach (1987) in their study of past changes in the African and Asian monsoon systems.

As in the previous sections, we will focus on the large-scale features of the tropical climate that are potentially relevant for precipitation in the central Andes: $200 \mathrm{hPa}$ zonal flow and low-level mixing ratio over the continental lowlands of South America. We note that while the model does not simulate the downward momentum mixing on the spatial scales described by Garreaud (1999), the seasonal relationship between central Andean precipitation and upper-level zonal flow is similar in the model and the modern observations. The onset of the wet season begins when the upper-level westerly flow abates with the southward shift of the subtropical jet stream (Fig. 6).

\subsection{Results}

To illustrate the different character of the precessional and glacial signatures in the tropics,
Fig. 7 shows the change in Dec-Feb (DJF) 200 $\mathrm{hPa}$ winds due to the glacial forcing (experiment 2-1) and to a change of the precessional phase by $180^{\circ}$ (experiment 3-1). For the glacial (Fig. 7a), there is a strengthening of the upper-air easterlies throughout the tropics. This is consistent with a stronger austral-summer Hadley cell, which increases due to the increased gradient in heating between the northern and southern hemispheres (A.J. Broccoli, personal communication). Over South America, this amounts to an increased easterly flow of up to $5 \mathrm{~m} / \mathrm{s}$, which, on the basis of the analysis in the previous sections, would tend to increase the moisture transport onto the Altiplano. The effect of precessional forcing on $200 \mathrm{hPa}$ circulation is dominated by more continentalscale circulations (Fig. 7b). These circulation changes are related to the orbitally forced changes in the land-sea contrast. When perihelion occurs during northern summer, the southern hemisphere receives less insolation during its summer. This results in a cooling relative to the present, which is large over land because of the small heat ca-
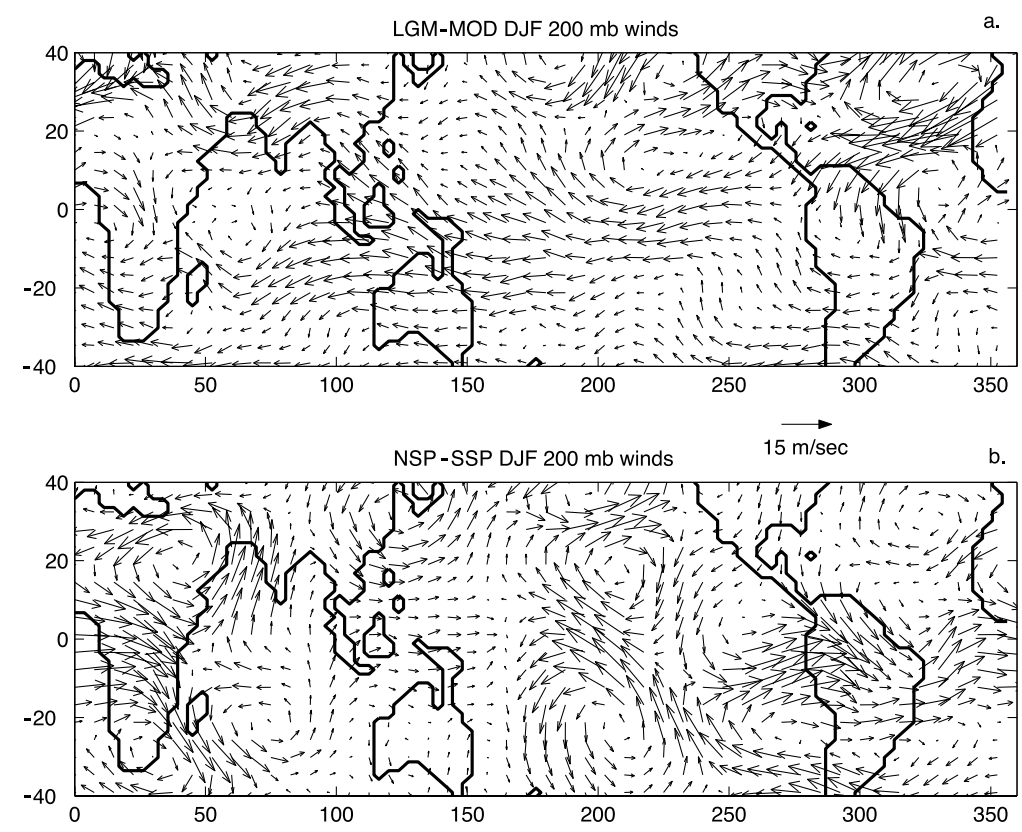

Fig. 7. (a) The vector difference in December-February $200 \mathrm{hPa}$ velocity for the LGMminus modern runs. Maximum vector length corresponds to $15 \mathrm{~m} / \mathrm{s}$. (b) Same as panel a, but for the difference between the run with the phase of the precessional forcing set to $180^{\circ}$ out-of-phase with the modern and the modern run. That is, the case of northern summer perihelion-southern summer perihelion. The scale of the vectors is the same as in panel a. 
pacity, and relatively small over the ocean because of the larger heat capacity of the mixed layer. This physical explanation has been invoked to explain large past changes in the northern hemisphere summer monsoons (Prell and Kutzbach, 1987). Over South America, the change in circulation represents a significant weakening of the equatorward portion of the austral-summer high pressure (upper-level anticyclone), and anomalous westerly flow over the Altiplano. Changes in wind strength are locally as large as $15 \mathrm{~m} / \mathrm{s}$, and would tend to dry the Altiplano. Upper-level circulation changes over South America during the boreal summer (June-August, not shown) associated with both forcings are generally smaller than for DJF. Because the westerlies during that season are strong, the relatively small forced-circulation changes would have little effect on conditions in the Altiplano.

Fig. 8 shows the modeled linear response to precession and glacial forcing in DJF precipitation over the Altiplano, $200 \mathrm{hPa}$ zonal wind over the region and surface mixing ratio over the continental lowlands upstream. The relationship between the zonal wind and precipitation that is observed on modern timescales does not appear to hold for the glacial case: anomalous easterly flow at $200 \mathrm{hPa}$ would tend to increase the transport of moist continental air to the Altiplano, which would lead to wetter conditions there, but instead the precipitation is slightly reduced. The reason for this is a large change in the mean climate at the glacial. Temperatures over South America are up to $3^{\circ} \mathrm{C}$ cooler (Broccoli,
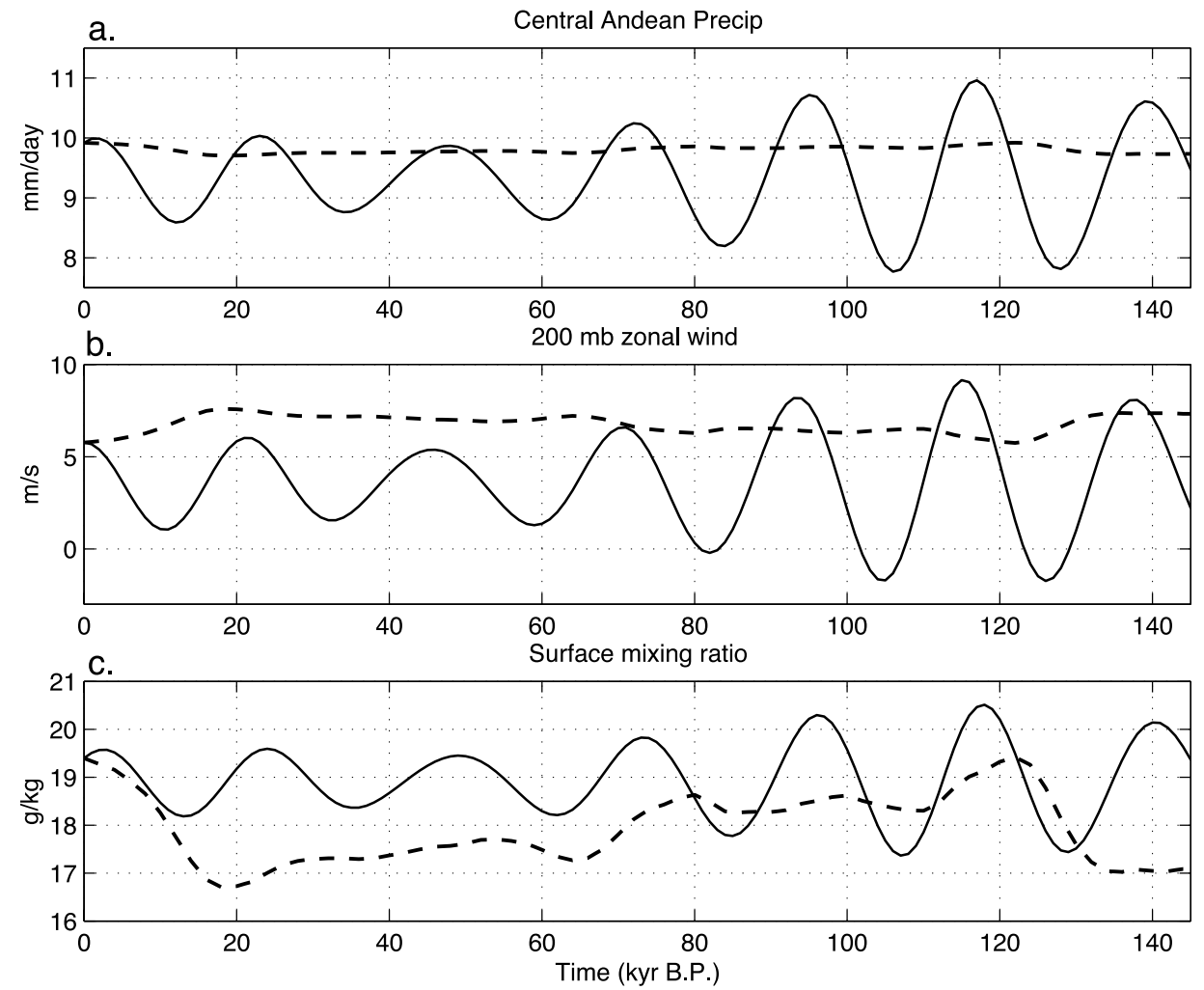

Fig. 8. Model linear response to precessional and glacial forcing for the last $145 \mathrm{kyr}$ for (a) DJF precipitation over the region of the Altiplano in the model $\left(60^{\circ}-70^{\circ} \mathrm{W}\right.$ and $\left.20^{\circ}-10^{\circ} \mathrm{S}\right)$ in $\mathrm{mm} / \mathrm{day}$, (b) DJF $200 \mathrm{hPa}$ zonal flow over the same region in $\mathrm{m} / \mathrm{s}$, and (c) DJF surface mixing ratio over the continental lowlands $\left(45^{\circ}-65^{\circ} \mathrm{W}\right.$ and $\left.20^{\circ}-0^{\circ} \mathrm{S}\right)$ in $\mathrm{g} / \mathrm{kg}$. Note that in panel b, easterly zonal flow is plotted as positive so that on all panels, higher values indicate tendency for wetter conditions on the Altiplano. Solid lines indicate the effect of precessional forcing on these quantities and dashed lines indicate glacial forcing.) 
2000), and with approximately constant surface relative humidity, this leads to a large reduction in the near-surface water vapor content over the continental lowlands (Fig. 8c). While the modern analysis in previous sections suggested that, on seasonal to interannual timescales, changes in the moisture sources over the Amazon are not an important control on Altiplano precipitation, on glacial timescales, drier conditions upstream tend to counteract the effect of the circulation on the moisture transport, resulting in little change in precipitation. In the case of precession, on the other hand, the effects of circulation and humidity are working in the same direction. More westerly winds occur when the continent is drier, both of which would lead to drier conditions on the Altiplano. Hence the precessional signal in precipitation over the Altiplano is far larger than the glacial signal.

We emphasize that these experiments serve to extend our understanding of the controls on the Altiplano climate to include the large climatic forcings of the past. They are not meant as a simulation of past climates. Ocean dynamics are fundamental in establishing the mean climate of the tropics, yet here we have used a climate model in which ocean heat transports are fixed at their modern values. This model configuration allows us to investigate the atmospheric response to the forcing. The results show the different nature and magnitude of the response to precessional and glacial forcing. The humidity and circulation fields can change in quite different ways for the different forcings, and may either reinforce each other (precession), or counteract each other (glacial). As a result, the precipitation response can be quite different. While these results are likely to be modified in the presence of coupled ocean-atmosphere interactions, we expect that, to first order, they are robust because they can be linked to very large changes in the meridional and zonal gradients of atmospheric heating.

\section{Conclusions}

In the modern climate, deep moist convection (and hence, convective rainfall) over the Altiplano is largely controlled by the moisture content within the ABL, with an activation threshold of about $5 \mathrm{~g} / \mathrm{kg}$. This high moisture value (with respect to the free tropospheric air at the same level) indicates moisture transport from the very humid continental lowland to the east of the central Andes, which is accomplished by regional-scale circulation that develops in response to the daytime heating of the sloping terrain. Despite variability on several timescales, the moisture content of the ABL over the continental lowlands always remains high (in excess of $12 \mathrm{~g} / \mathrm{kg}$ ). Thus, moisture variability over the Altiplano appears to be related to changes in the intensity of its transport from the east. The intensity and duration of the easterly upslope flow (and its counterpart over the dry, western slope) is modulated by the sign and strength of upper-level large-scale zonal flow over the central Andes. Easterly (westerly) flow aloft favors the easterly (westerly) upslope flow, increasing the transport of moist (dry) air into the Altiplano.

The large-scale zonal flow is in turn the superposition of transient (synoptic or intraseasonal) disturbances and the seasonal mean flow. Transient disturbances are associated with Rossby waves propagating from the $\mathrm{SH}$ midlatitudes and amplifying over subtropical South America, resulting in episodic fluctuations of the zonal flow with a period on the order of 1-2 weeks. These fluctuations lead to actual easterly winds over the central Andes only under favorable background flow: easterly or weak westerly. In the modern climate, this latter condition is met in a fairly narrow window of time, December to March, during which the rainy season develops with its characteristic episodic evolution. On the interannual timescales, the large-scale zonal flow at tropical-subtropical latitudes further weakens during La Niña years, fostering an extended, or more active, rainy season over the Altiplano. The opposite effect tends to occur during El Niño years, when the warming of the tropical troposphere leads to a stronger than normal westerly flow upstream and over the central Andes.

The focus on the large-scale controls on the climate of the Altiplano lends itself well to studying perturbations to the modern conditions using 
GCMs. We investigated the effect of orbital and glacial forcing on the factors that control the Altiplano climate. On the basis of the results shown in Section 4, we surmise that it is sensible to consider separately these two different forcings because they are so different in character and magnitude. The glacial response in $200 \mathrm{hPa}$ circulation is small relative to the precessional response, while the glacial change in moisture distribution is relatively large. Thus for the glacial state, the circulation and humidity change in ways that tend to have counteracting effects on the supply of moisture to the Altiplano, and there is almost no glacial precipitation signal in the Altiplano in the model. On the other hand, the effects of circulation and humidity changes in response to precessional forcing tend to reinforce each other, and the Altiplano precipitation signal is large. These results raise the possibility that the orbital and glacial signatures, both on a large scale and in the region of the Altiplano, may be quite distinct in the paleoclimate record.

We have provided evidence for the primary importance of the upper-air circulation on the Altiplano climate, and used this framework to understand climate change in the region on various timescales. There are undoubtedly other climatic factors of relevance. The results for the glacial climate, for example, suggest a potential effect of upstream changes in the moisture available for transport to the Altiplano. Future research will refine and quantify the relative influences of different climatic phenomena to provide a more complete framework for studying the modern climate of the Altiplano and its history.

\section{Acknowledgements}

The NCEP-NCAR reanalysis and OLR data were provided by the NOAA Climate Diagnostics Centers. The authors gratefully acknowledge Dr. A. Broccoli for his contribution to the modeling component of this work. We also thank the two reviewers for their helpful input. R.G. was partially supported by Fondecyt (Chile) Grant 1000913 and by the DID, Universidad de Chile, Grant I002-99. M.V. was partially supported by NSF
Grant ATM99-09201. A.C. was supported by NSF Grant ATM 99-86515.

\section{References}

Aceituno, P., 1988. On the functioning of the Southern Oscillation in the South American sector. Part I: Surface climate. Mon. Weather Rev. 116, 505-524.

Aceituno, P., 1998. Climate elements of the South American Altiplano. Rev. Geofis. 44, 37-55.

Aceituno, P., Montecinos, A., 1993. Circulation anomalies associated with dry and wet periods in the South American Altiplano. Proc. Fourth Int. Conf. on Southern Hemisphere Meteorology, Hobart, Australia. Am. Meteor. Soc., pp. 330-331.

Aceituno, P., Montecinos, A., 1997a. Patterns of convective cloudiness in South America during austral summer from OLR pentads. Preprints, Fifth Int. Conf. on Southern Hemisphere Meteorology and Oceanography, Pretoria, South Africa. Am. Meteor. Soc., pp. 328-329.

Aceituno, P., Montecinos, A., 1997b. Meteorological field experiments in the South American Altiplano. Preprints, Fifth Int. Conf. on Southern Hemisphere Meteorology and Oceanography, Pretoria, South Africa. Am. Meteor. Soc., pp. 330-331.

Arnaud, Y., Muller, F., Vuille, M., Ribstein, P., 2001. El Niño - Southern Oscillation (ENSO) influence on a Sajama volcano glacier from 1963 to 1998 as seen from Landsat data and aerial photography. J. Geophys. Res. 106, 17773-17784.

Broccoli, A.J., 2000. Tropical cooling at the last glacial maximum: An atmosphere-mixed layer ocean model simulation. J. Clim. 13, 951-976.

Broecker, W.S., 1995. The Glacial World According to Wally. Lamont-Doherty Earth Observatory, Palisades, NY, 318 pp.

Chaffaut, I., Coudrian-Ribstein, A., Michelot, J.L., Pouyaud, B., 1998. Précipitations d'altitude du Nord-Chili, origine des sources de vapeur et données isotopiques. Bull. Inst. Fr. étud. Andin. 27, 367-384.

Enfield, D.B., 1996. Relationship of inter-American rainfall to tropical Atlantic and Pacific SST variability. Geophys. Res. Lett. 23, 3305-3308.

Fuenzalida, H., Rutllant, J., 1987. Origen del vapor de agua que precipita sobre el altiplano de Chile. Proc. II Congreso InterAmericano de Meteorología, Buenos Aires, Argentina, pp. 6.3.1-6.3.4.

Garreaud, R.D., Wallace, J.M., 1997. The diurnal march of convective cloudiness over the Americas. Mon. Weather Rev. 125, 3157-3171.

Garreaud, R.D., 1999. Multi-scale analysis of the summertime precipitation over the central Andes. Mon. Weather Rev. 127, 901-921.

Garreaud, R.D., Battisti, D.S., 1999. Interannual (ENSO) and interdecadal (ENSO-like) variability in the Southern Hemisphere tropospheric circulation. J. Clim. 12, 2113-2123.

Garreaud, R.D., 2000. Intraseasonal variability of moisture 
and rainfall over the South American Altiplano. Mon. Weather Rev. 128, 3346-3379.

Garreaud, R., Aceituno, P., 2001. Interannual rainfall variability over the South American Altiplano. J. Clim. 14, 2779 2789.

Hardy, D.R., Vuille, M., Braun, C., Keimig, F., R.S. Bradley, R.S., 1998. Annual and daily meteorological cycles at high altitude on a tropical mountain. Bull. Am. Meteor. Soc. 79, 1899-1913.

Horel, J., Hahmann, A., Geisler, J., 1989. An investigation of the annual cycle of convective activity over the tropical Americas. J. Clim. 2, 1388-1403.

Houze, R.A., Jr., 1997. Stratiform precipitation in regions of convection: A meteorological paradox? Bull. Am. Meteor. Soc. 78, 2179-2196.

Imbrie, J. et al., 1992. On the structure and origin of major glaciation cycles. Part I: Linear responses to Milankovitch forcing. Paleoceanography 7, 701-738.

Kalnay, E., et al., 1996. The NCEP/NCAR 40-years reanalysis project. Bull. Am. Meteor. Soc. 77, 437-472.

Lenters, J.D., Cook, K.H., 1997. On the origin of the Bolivian high and related circulation features of the South American climate. J. Atmos. Sci. 54, 656-677.

Lenters, J.D., Cook, K.H., 1999. Summertime precipitation variability over South America: role of the large-scale circulation. Mon. Weather Rev. 127, 409-431.

Marengo, J.A., Hastenrath, S., 1993. Case studies of extreme climatic events in the Amazon basin. J. Clim. 6, 617-627.

Mechoso, C.R., Lyons, S.W., Spahr, J.A., 1990. The impact of sea surface temperature anomalies on the rainfall over northeast Brazil. J. Clim. 3, 812-826.

Meisner, B., Arkin, P., 1987. Spatial and annual variations in the diurnal cycle of the large-scale tropical convective cloudiness and precipitation. Mon. Weather Rev. 115, 2009-2032.

Nobre, P., Shukla, J., 1996. Variations of sea surface temperature, wind stress and rainfall over the tropical Atlantic and South America. J. Clim. 9, 2464-2479.

Nogues-Paegle, J., Mo, K.C., 1997. Alternating wet and dry conditions over South America during summer. Mon. Weather Rev. 125, 279-291.

Prell, W.L., Kutzbach, J.E., 1987. Monsoon variability over the last 150,000 years. J. Geophys. Res. 92, 8411-8425.
Rao, G.V., Erdogan, S., 1989. The atmospheric heat source over the Bolivian plateau for a mean January. Bound. Layer Met. 17, 45-55.

Ronchail, J., 1995. Variabilidad interanual de las precipitaciones en Bolivia. Bull. Inst. Fr. étud. Andines 46, 13-33.

Rutllant, J., Ulriksen, P., 1979. Boundary layer dynamics of the extremely arid northern Chile: the Antofagasta field experiment. Bound. Layer Met. 17, 45-55.

Thompson, L.G., Mosley-Thompson, E., Morales-Arnao, B., 1984. El Niño Southern Oscillation as recorded in the stratigraphy of the tropical Quelccaya ice cap, Peru. Science 226, 50-52.

Trenberth, K.E., Stepaniak, D.P., 2001. Indices of El Niño evolution. J. Clim. 14, 1697-1701.

Vuille, M., Ammann, C., 1997. Regional snowfall patterns in the high, arid Andes. Clim. Change 36, 413-423.

Vuille, M., Hardy, D.R., Braun, C., Keimig, F., Bradley, R.S., 1998. Atmospheric circulation anomalies associated with 1996/97 summer precipitation events on Sajama ice cap, Bolivia. J. Geophys. Res. 103, 11191-11204.

Vuille, M., 1999. Atmospheric circulation over the Bolivian Altiplano during dry and wet periods and extreme phases of the Southern Oscillation. Int. J. Climatol. 19, 15791600.

Vuille, M., Bradley, R.S., 2000. Mean annual temperature trends and their vertical structure in the tropical Andes. Geophys. Res. Lett. 27, 3885-3888.

Vuille, M., R.S. Bradley, Keimig, F., 2000a. Interannual climate variability in the Central Andes and its relation to tropical Pacific and Atlantic forcing. J. Geophys. Res. 105, $12447-12460$.

Vuille, M., Bradley, R.S., Keimig, F., 2000b. Climatic variability in the Andes of Ecuador and its relation to tropical Pacific and Atlantic sea surface temperature anomalies. J. Clim. 13, 2520-2535.

Whiteman, C.D., 1990. Observations of thermally driven wind systems in mountainous terrain. In: Blumen, W. (Ed.), Atmospheric Processes over Complex Terrain. Meteorological Monographs 23, chapter 2. American Meteorological Society, Boston, MA.

Zhou, J., Lau, K.M., 1998. Does a monsoon climate exist over South America? J. Clim. 11, 1020-1040. 